\title{
The secretory patterns of growth hormone in pregnant and hysterectomized ewes
}

\author{
Kaïs Hussain Al-Gubory ${ }^{1}$, Philippe Bolifraud ${ }^{2}$, Guy Kann ${ }^{2}$ and Claire Soulier ${ }^{1}$ \\ INRA, ${ }^{1}$ Unité de Recherches de Physiologie Animale, ${ }^{2}$ Unité de Recherches sur le Placenta et la Périnatalité, 78352 Jouy-en-Josas cedex, France \\ (Correspondence should be addressed to K H Al-Gubory; Email: algubory@jouy.inra.fr)
}

\begin{abstract}
This work was undertaken to determine the secretory patterns of GH during pregnancy, and to evaluate the effect, if any, of hysterectomy during early pregnancy on subsequent secretion of GH in ewes. The concentrations of GH were determined in the plasma of jugular blood samples collected at 15-min intervals during a 6-h period on days 20,40,60, 80, 100 and 120 post-mating, and three times per week between days 29 and 120 post-mating from 5 pregnant ewes and from 5 ewes from which the gravid uterus was removed on day 30 post-mating. A pulse analysis program (Pulsar) was used to analyse the secretory patterns of $\mathrm{GH}$ in individual profiles of the serial sampling period. In the two groups of ewes, peripheral concentrations of GH fluctuated in an episodic manner during the frequent blood sampling of any stage of the post-mating period examined. The overall $\mathrm{GH}$ concentrations, the basal GH concentrations, the frequency and the amplitude of GH pulses remained fairly stable between days 20 and 120 post-mating in the two groups of ewes. The parameters of GH secretion were not different between the two groups of ewes. The secretory patterns of GH, as determined in plasma of blood collected three times per week between days 29 and 120 post-mating were also not different between the two groups of ewes.

In conclusion, results of this study show that (i) the pulsatile secretion of GH does not change as pregnancy advances, and (ii) hysterectomy performed during early pregnancy does not subsequently affect the secretory patterns of GH. These findings suggest that the gravid uterus and/or the fetoplacental unit secretory products are unlikely to be involved in the control of $\mathrm{GH}$ secretion during pregnancy in the ewe.
\end{abstract}

European Journal of Endocrinology 141 83-89

\section{Introduction}

In mammals, the detailed information on ovarian follicular development throughout pregnancy comes from studies in cattle and sheep (1). These investigations have shown that follicular growth decreases progressively with advancing pregnancy, and the largest follicles never exceed a diameter larger than $3 \mathrm{~mm}$ and $2 \mathrm{~mm}$ during the last month of pregnancy in ovaries of cattle and sheep respectively. In the ewe, hysterectomy performed on day 30 of pregnancy allows the maintenance of corpus luteum (CL) structures and progesterone secretion $(2,3)$ at least until day 120 post-mating and subsequently enhances follicular growth, which is characterized by the presence on day 120 post-mating of healthy follicles larger than $3 \mathrm{~mm}$ (2), without changes in follicle-stimulating hormone (FSH) and luteinizing hormone (LH) secretion (3). These findings suggest that the gravid uterus and/or the fetoplacental unit exert a suppressing action at the ovarian level, thereby preventing the development of large healthy follicles during late pregnancy. Although the pivotal role of FSH and LH in the regulation of ovarian follicular development and function is well established in mammalian species, growth hormone $(\mathrm{GH})$ may be involved in these processes. In vitro studies demonstrate that GH enhances gonadotrophin-induced differentiation of rat granulosa cells $(4,5)$ and stimulates steroidogenesis by rat (4) and human (6) granulosa cells and by perfused rabbit ovaries (7). In vivo treatment with $\mathrm{GH}$ has been shown to amplify the response of the human ovaries to gonadotrophin stimulation $(8,9)$. In vivo treatment with GH has also been shown to increase the number of follicles of $2-5 \mathrm{~mm}$ in heifers (10), the number of follicles of $6-15 \mathrm{~mm}$ in lactating cows, the size of the second largest follicle in both lactating and non-lactating cows (11) and the number of follicles of $2-3 \mathrm{~mm}$ in cyclic ewes (12). In hypophysectomized ewes, gonadotrophin treatment fails to stimulate follicular growth and ovulation (13) unless $\mathrm{GH}$ is also administered (14). During the ovine oestrous cycle, both pituitary GH mRNA and GH release peak near the time 
of ovulation, suggesting a role for $\mathrm{GH}$ in ovarian follicular development and maturation (15).

Despite the general acceptance of the importance of $\mathrm{GH}$ in ovarian follicular development, the secretory patterns of $\mathrm{GH}$ during pregnancy have not been characterized by frequent blood sampling suitable for the determination of pulse parameters. These GH secretory patterns may be of utmost importance for our understanding of changes in ovarian follicular dynamics during pregnancy. Available data suggest that hysterectomy and uterine extract influence the synthesis and release of $\mathrm{GH}$ in the rat (16-18). Therefore, the aims of the present study were to determine: (i) the secretory patterns of GH during pregnancy and (ii) the effect, if any, of hysterectomy during early pregnancy on subsequent secretion of $\mathrm{GH}$ in ewes.

\section{Materials and methods}

\section{Animals and management}

Ewes of the Préalpes-du-Sud breed were used in this study. Oestrus was synchronized using a 14-day treatment with intravaginal pessaries containing $40 \mathrm{mg}$ fluorogestone acetate (Intervet, Angers, France). After removal of the pessaries, the ewes were given $400 \mathrm{IU}$ pregnant mares' serum gonadotrophin (Intervet) and were mated with fertile rams. The ewes were housed indoors under conditions of natural daylength and temperature. They were provided daily with a diet of hay, straw and concentrates and had free access to mineral licks and water.

\section{Experimental design}

On day 30 of pregnancy, 5 ewes per group were assigned at random to be either hysterectomized (Group $\mathrm{H})$ or control sham-operated (Group C). General anaesthesia was induced by intravenous injection of pentobarbitone (Sanofi, Paris, France) and thiopentone (Abbott, Aubervilliers, France) and maintained by constant inhalation of a mixture of halothane and oxygen. The reproductive tract was exteriorized through a midventral incision and the CL of each ewe were marked with Indian ink for subsequent identification. Hysterectomy was performed as described previously (2). The ewes that underwent sham operation were laparotomized and the uterus and ovaries were exteriorized and manipulated. All ewes were treated with penicillin ( $10^{6}$ IU per day) for 3 consecutive days after surgery. For the determination of pulsatile $\mathrm{GH}$ secretion, blood samples $(3 \mathrm{ml})$ were collected at 15 -min intervals during a 6 -h period beginning at $0900 \mathrm{~h}$ on days 20, $40,60,80,100$ and 120 post-mating. Blood samples were also collected three times per week (on Monday, Wednesday and Friday) between days 29 and 120 postmating. Blood samples were taken from the jugular vein into evacuated heparinized tubes. After centrifugation
(4000 r.p.m. for $30 \mathrm{~min}$ ) plasma was separated and stored at $-20^{\circ} \mathrm{C}$ until assayed for $\mathrm{GH}$.

\section{Assay of GH}

Concentrations of GH were measured using a doubleantibody radioimmunoassay (19). The assay sensitivity was $0.6 \mathrm{ng} / \mathrm{ml}$. The intra- and interassay coefficients of variation were $<10 \%$.

\section{Data analysis}

The Pulsar Algorithmic Program (20) for the study of pulsatile hormone secretion was used to calculate the basal concentrations, and the frequency and the amplitude of episodic GH release (pulses) in individual profiles of the serial sampling period. The $G$ values, or number of assay coefficients of variation by which a pulse must exceed the base line were: $\mathrm{G}(1)=3.80$, $\mathrm{G}(2)=2.60, \mathrm{G}(3)=1.92, \mathrm{G}(4)=1.46$ and $\mathrm{G}(5)=1.13$ for pulses with 1-5 consecutive elevated points respectively. Data were subjected to two-way analysis of variance for repeated measurements using general models procedures (21). A logarithmic transformation was applied to the data to equilize variance. The number of pulses +0.5 was subjected to square-root transformation before analysis. The median amplitude of $\mathrm{GH}$ pulses detected within the individual profile of each ewe was calculated, and the non parametric test of Mann and Whitney was used to compare the median of the amplitude of $\mathrm{GH}$ pulses between the two groups of ewes.

\section{Results}

The number of CL per ewe recorded on the day of surgery (day 30 post-mating) was confirmed at laparotomy performed on day 130 post-mating. All the ewes had 1 or $2 \mathrm{CL}$. Individual profiles of $\mathrm{GH}$ concentrations in plasma of jugular blood samples collected at 15 -min intervals during a 6 -h period on days $20,40,60,80,100$ and 120 post-mating from the 5 pregnant and the 5 hysterectomized ewes are shown in Figs 1 and 2 respectively. In the two groups of ewes, the concentrations of $\mathrm{GH}$ fluctuated in an episodic manner. The characterstics of pulsatile GH secretion are shown in Table 1. The overall GH concentrations, the basal GH concentrations, the frequency and the amplitude of $\mathrm{GH}$ pulses remained fairly stable between days 20 and 120 post-mating in the two groups of ewes. None of the parameters of GH secretion were significantly different between the two groups of ewes (treatment effect, $P>0.05$; treatment by time interaction, $P>0.05)$. Individual profiles of $\mathrm{GH}$ concentrations in plasma of jugular blood samples collected three times per week between days 29 and 120 post-mating from the 5 pregnant and the 5 hysterectomized ewes are shown in Fig. 3. The overall secretory pattern of GH 


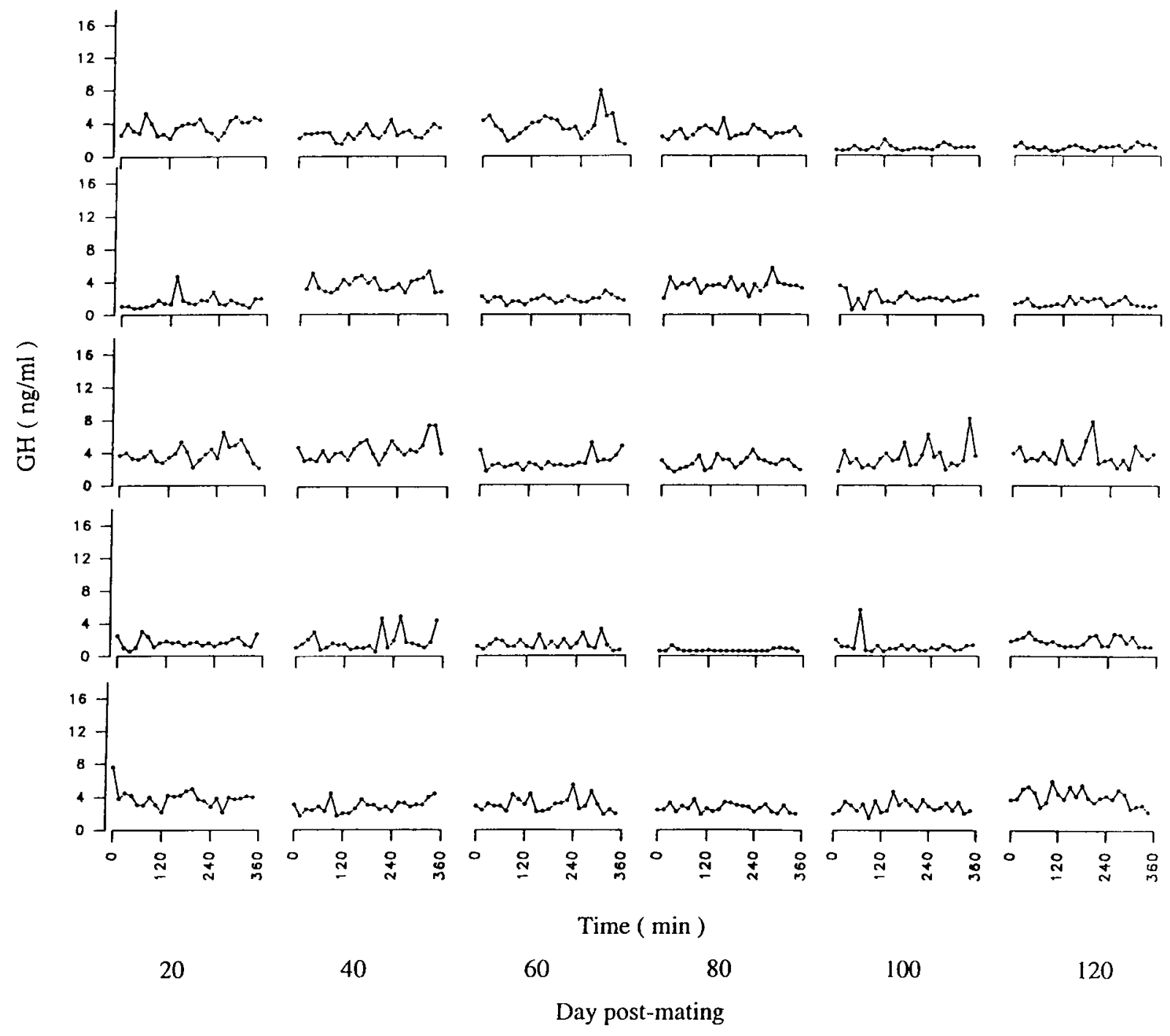

Figure 1 Profiles of GH concentrations in plasma of jugular blood samples collected every 15 min during a 6-h period on days 20, 40, 60, 80 , 100 and 120 post-mating from 5 sham-operated pregnant ewes. Sham operation was carried out on day 30 post-mating.

was not different between the two groups of ewes. In the two groups of ewes, occasional GH secretory spikes of varying magnitude were observed. Relatively low and constant basal $\mathrm{GH}$ concentrations were maintained between days 29 and 120 post-mating in the two groups of ewes.

\section{Discussion}

Only limited information is available regarding the secretion of GH in pregnant sheep. Previous studies on the secretion of $\mathrm{GH}$ in the ewe have been restricted to measurment of GH in only one blood sample collected at irregular and at infrequent intervals during the last two trimesters (22) or the last trimester (23) of pregnancy. Others (24) measured GH in blood samples taken every hour for a 24-hour period during late pregnancy only.
Since GH is secreted episodically in mammalian species, including sheep (25), it is generally agreed that GH secretion must be studied by repeated measurement over several hours. In the present study, the secretion of $\mathrm{GH}$ has been well characterized by intensive blood sampling (every $15 \mathrm{~min}$ for a 6 -h period) over relatively frequent and regular intervals throughout pregnancy. We showed that the secretion of $\mathrm{GH}$ is pulsatile during pregnancy in the ewe. By using frequent blood sampling, at 15-min (26) or at 5-min (27) intervals, the pulsatile secretion of $\mathrm{GH}$ has also been demonstrated during late pregnancy in the rat. The mean concentrations of $\mathrm{GH}$ and the frequency and the amplitude of $\mathrm{GH}$ pulses remained fairly stable between day 20 and day 120 of pregnancy (present study). These results on peripheral concentrations of $\mathrm{GH}$ are similar to those reported by others (28) who showed no change in 


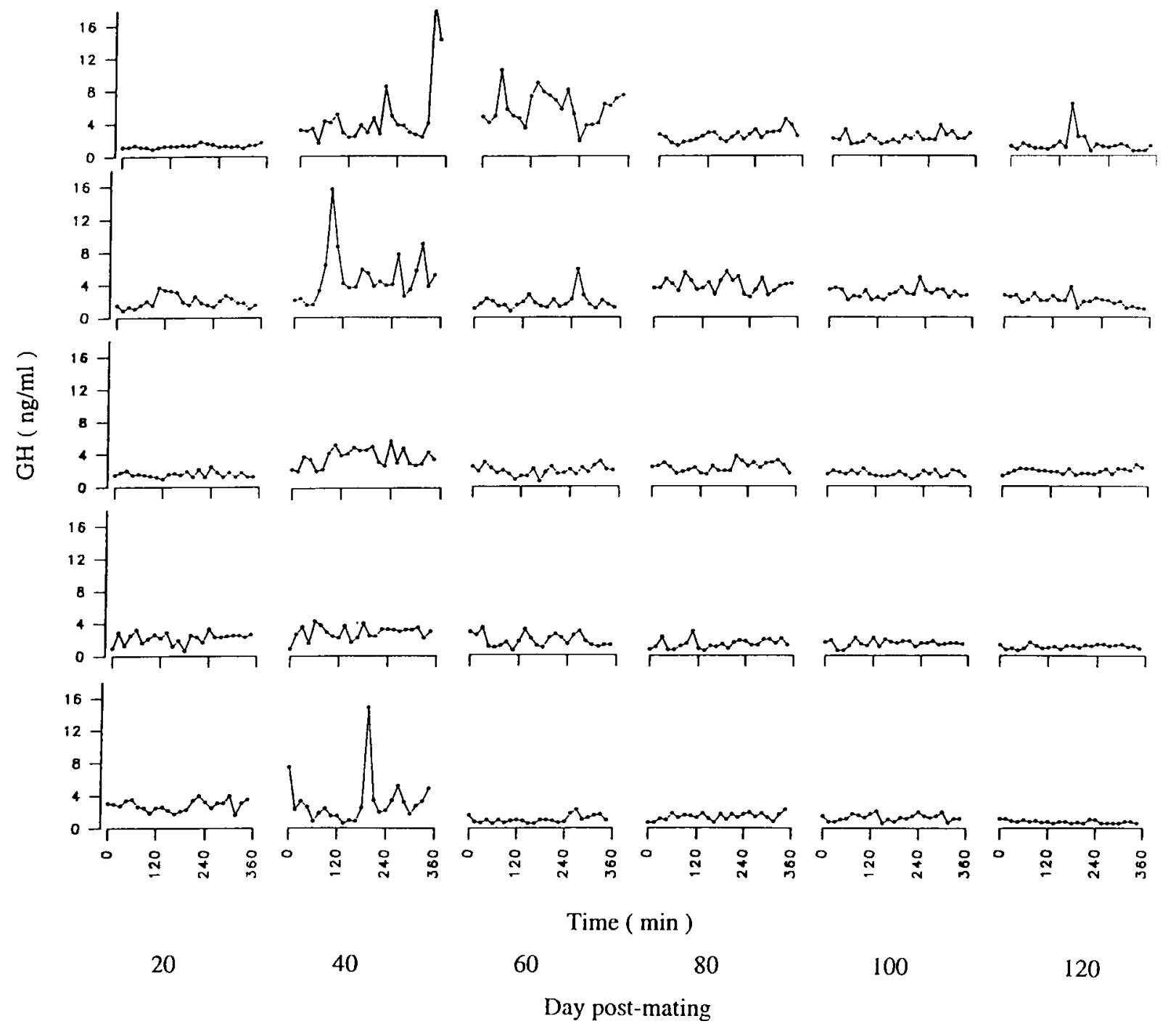

Figure 2 Profiles of GH concentrations in plasma of jugular blood samples collected every 15 min during a 6-h period on days $20,40,60,80$, 100 and 120 post-mating from 5 hysterectomized ewes. Surgical removal of the gravid uterus was carried out on day 30 post-mating.

Table 1 Characteristics of GH secretion in 5 pregnant ewes (Group C) and in 5 hysterectomised ewes (Group H). Hysterectomy was carried out on day 30 of pregnancy. Values for GH concentration, basal GH concentration and pulse frequency are means \pm S.E.M. Values for pulse amplitude are median ( 0.95 confidence interval).

\begin{tabular}{|c|c|c|c|c|c|c|}
\hline \multirow[b]{2}{*}{ Parameter } & \multicolumn{6}{|c|}{ Day post-mating } \\
\hline & 20 & 40 & 60 & 80 & 100 & 120 \\
\hline \multicolumn{7}{|l|}{ Group C } \\
\hline GH conc. (ng/ml) & $2.9 \pm 0.5$ & $3.1 \pm 0.4$ & $2.7 \pm 0.4$ & $2.5 \pm 0.5$ & $2.1 \pm 0.5$ & $2.4 \pm 0.6$ \\
\hline Basal GH conc. (ng/ml) & $2.5 \pm 0.5$ & $2.7 \pm 0.5$ & $2.2 \pm 0.4$ & $2.3 \pm 0.5$ & $1.7 \pm 0.4$ & $2.1 \pm 0.6$ \\
\hline Pulse frequency $/ 6 \mathrm{~h}$ & $3.8 \pm 0.2$ & $3.4 \pm 0.5$ & $4.0 \pm 0.8$ & $3.6 \pm 0.7$ & $4.6 \pm 0.7$ & $4.0 \pm 0.3$ \\
\hline Pulse amplitude (ng/ml) & $1.6(0.8-2.4)$ & $1.8(1.5-2.9)$ & $1.0(0.5-2.2)$ & $0.9(0.7-1.4)$ & $1.0(0.7-2.7)$ & $1.3(0.6-1.6)$ \\
\hline \multicolumn{7}{|l|}{ Group H } \\
\hline $\mathrm{GH}$ conc. $(\mathrm{ng} / \mathrm{ml})$ & $2.0 \pm 0.3$ & $3.9 \pm 0.4$ & $2.1 \pm 0.4$ & $2.4 \pm 0.5$ & $1.9 \pm 0.3$ & $1.4 \pm 0.2$ \\
\hline Basal GH conc. (ng/ml) & $1.8 \pm 0.3$ & $2.9 \pm 0.4$ & $1.6 \pm 0.3$ & $2.1 \pm 0.4$ & $1.7 \pm 0.3$ & $1.3 \pm 0.3$ \\
\hline Pulse frequency $/ 6 \mathrm{~h}$ & $3.2 \pm 0.5$ & $5.2 \pm 0.4$ & $4.0 \pm 0.6$ & $4.2 \pm 0.7$ & $3.8 \pm 0.5$ & $2.8 \pm 0.9$ \\
\hline Pulse amplitude ( $\mathrm{ng} / \mathrm{ml})$ & $0.8(0.3-1.3)$ & $2.3(1.6-4.5)$ & $1.2(1.0-3.0)$ & $0.9(0.5-1.7)$ & $1.2(0.7-1.3)$ & $0.6(0.4-1.2)$ \\
\hline
\end{tabular}



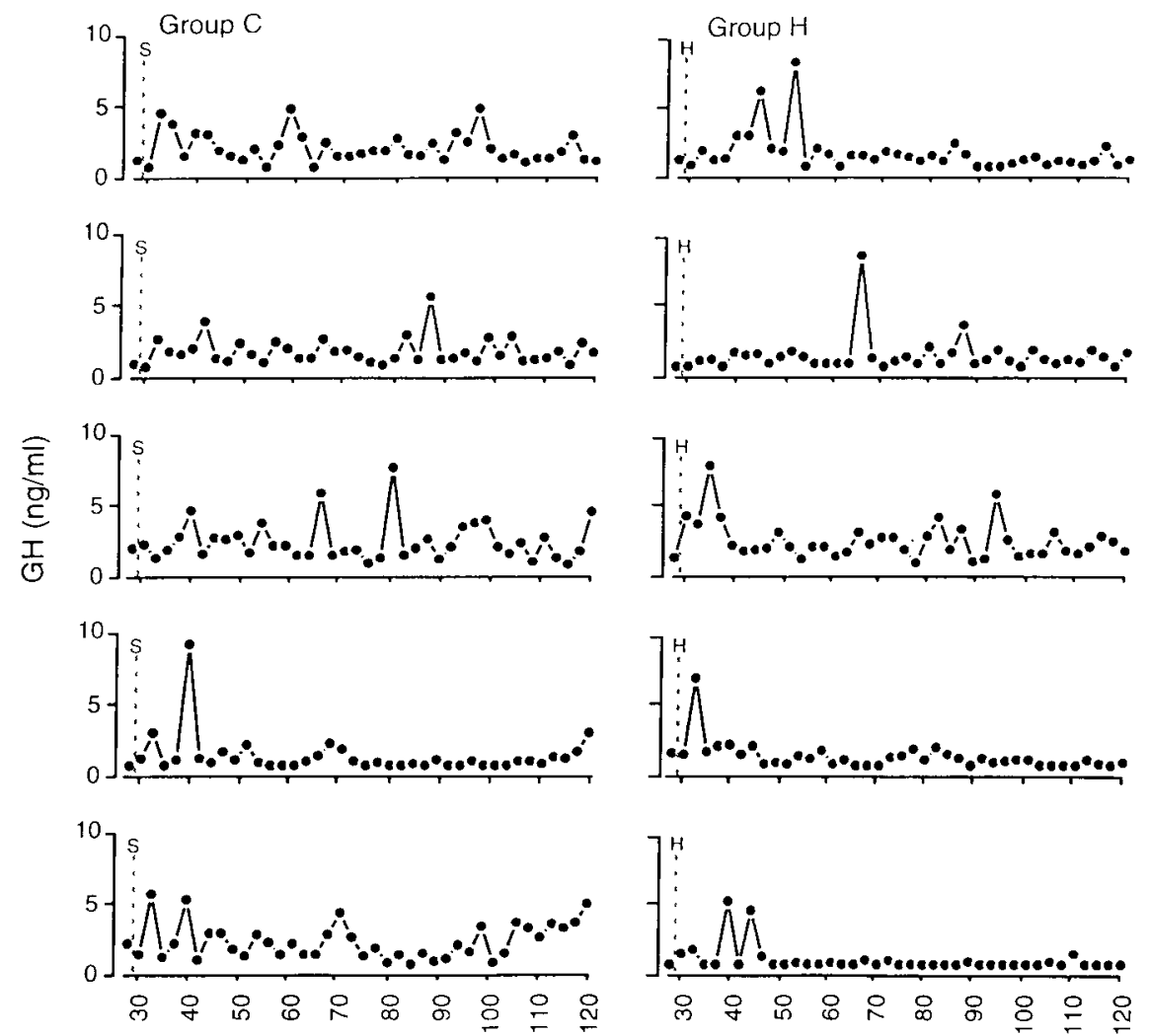

Day post-mating

Figure 3 Profiles of $\mathrm{GH}$ concentrations in plasma of jugular blood collected three times per week between days 29 and 120 post-mating from 5 sham-operated pregnant ewes (Group C) and from 5 hysterectomized ewes (Group H). Sham operation (S) or surgical removal of the gravid uterus $(\mathrm{H})$ was carried out on day 30 post-mating.

the pituitary content of GH with advancing pregnancy. In women, unlike the rat and the ewe, the secretion of pituitary $\mathrm{GH}$ progressively declines as pregnancy advances, and is abolished during late pregnancy (29, 30). In women, the placenta produces an alternative form of GH (31) which appears in the circulation at midpregnancy and increases thereafter up to term $(29,30)$. The placental $\mathrm{GH}$ variant is secreted continuously without pulses during late pregnancy in women (30). Placental removal by caesarean section during late pregnancy in women results in a rapid fall in peripheral $\mathrm{GH}$ concentrations, indicating that high levels of $\mathrm{GH}$ are derived from the placenta (32). In contrast, the lack of effect of hysterectomy performed on day 30 of pregnancy on subsequent secretion of GH (present study) indicates that circulating $\mathrm{GH}$ during pregnancy in the ewe is derived from the pituitary. A pituitary origin of $\mathrm{GH}$ secretion in the pregnant rat is supported by the fact that hypophysectomy results in undetectable levels of $\mathrm{GH}(27)$.

The present study is the first report describing plasma concentrations of $\mathrm{GH}$ in ewes hysterectomized during early pregnancy. Hysterectomy performed on day 30 of pregnancy had no subsequent effect on the patterns of GH secretion, as demonstrated by the absence of differences between pregnant and hysterectomized ewes in plasma concentrations of GH. Thus, the gravid uterus and/or the feto-placental unit secretory products are unlikely to be involved in the control of $\mathrm{GH}$ secretion during pregnancy in the ewe. Dlamini et al. (33) showed that plasma concentrations of $\mathrm{GH}$ during late pregnancy (days 99-114) in gilts are similar to those measured at equivalent stages in unmated gilts hysterectomized on days 6-8 after estrus. Kornalijnslijper et al. (34) showed that plasma concentrations of $\mathrm{GH}$ during pregnancy in goats are similar to those measured at equivalent stages in goats hysterectomized on days 32-58 of pregnancy.

On day 120 (2) and day 50 (35) after mating, the ovaries of ewes from which the gravid uteri were removed on day 30 of pregnancy contain healthy follicles $>3 \mathrm{~mm}$, while those of pregnant ewes do not. Since peripheral concentrations of FSH (3) and GH (present study) do not change after hysterectomy performed on day 30 of pregnancy, and are similar in pregnant and hysterectomized ewes between days 20 and 120 post-mating, the inhibitory effects of pregnancy on antral follicular development are probably not 
mediated through changes in the secretion of these pituitary hormones. Evidence is available to suggest that non-steroidal factor(s) from the sheep placenta of late pregnancy inhibit directly, at the ovarian level, aromatase activity (36) and follicular growth (37).

There is evidence to indicate that the mRNA for $\mathrm{GH}$ receptor is abundantly localized in granulosa cells of rat (38) and ewe (39) ovarian follicles. The failure of antral follicles in hypophysectomized ewes to grow in response to exogenous gonadotrophins (13) is attributed to a reduction of mRNA for $\mathrm{GH}$ receptor in the membrana granulosa of follicles (39). Cattle with a GH receptor deficiency fail to maintain follicular development during the oestrous cycle (40). Thus, other factors that could also contribute to the inhibition of antral follicular growth during late pregnancy are insufficient follicular receptors for $\mathrm{GH}$, that render the follicles refractory to endogenous stimulation. It remains to be elucidated if changes in ovarian follicular development during pregnancy are accompanied by variations in the follicular expression of $\mathrm{GH}$ receptor.

In conclusion, results of the present study show that (i) the pulsatile secretion of $\mathrm{GH}$ does not change as pregnancy advances, and (ii) hysterectomy performed on day 30 of pregnancy does not subsequently affect the secretory patterns of GH. Taken together, these findings suggest the gravid uterus and/or the fetoplacental unit secretory products are unlikely to be involved in the control of $\mathrm{GH}$ secretion during pregnancy in the ewe.

\section{Acknowledgements}

The authors thank A Solari for statistical analysis and the staff of the sheep shed for outstanding technical help and animal management. We are grateful to Prof. Charles Thibault for his critical evaluation and comments.

\section{References}

1 Rüsse I. Größe des corpus luteum und follikelanbildung während des gravidität bei rind und schaf. Zuchthygiene 1971 6 126-134.

2 Al-Gubory KH, Paly J \& Martinet J. Effects of pregnancy and hysterectomy on antral follicular population and growth in the ewe. Animal Reproduction Science 199229 213-223.

3 Al-Gubory KH, Blanc MR \& Poirier JC. Effects of pregnancy and hysterectomy on pituitary gonadotrophin secretion in the ewe. Animal Reproduction Science 199435 209-221.

4 Jia XC, Kalmyn J \& Hsueh AJW. Growth hormone enhances follicle-stimulating hormone-induced differentiation of cultured rat granulosa cells. Endocrinology 1986188 1401-1409.

5 Hutchinson LA, Findlay JK \& Herington AC. Growth hormone and insulin-like growth factor-I accelerate PMSG-induced differentiation of granulosa cells. Molecular Cell Endocrinology 198855 61-69.

6 Manson HD, Martkaninen H, Beard RW, Fulghesu AM, Caruso A \& Mancuso S. Direct gonadotropin effect of growth hormone on oestradiol production by human granulosa cells. Journal of Endocrinology $1990126 \mathrm{R} 1-\mathrm{R} 4$.
7 Yoshimura Y, Nakamura Y, Koyama N, Iwashita M, Adashi T \& Takeda Y. Effects of growth hormone on follicle growth, oocyte maturation and ovarian steroidogenesis. Fertility and Sterility $199359113-117$.

8 Blumenfeld Z \& Lunenfeld B. The potentiality effect of growth hormone on follicle stimulation with human menopausal gonadotropin in a panhypopituitary patient. Fertility and Sterility $198952328-331$.

9 Homburg R, Eshel A, Abdalla HI \& Jacobs HS. Growth hormone facilitates ovulation induction by gonadotropins. Clinical Endocrinology $198829113-117$.

10 Gong JG, Bramley T \& Webb R. The effect of recombinant bovine somatotropin on ovarian function in heifers: follicular populations and peripheral hormone. Biology of Reproduction 199145 941-949.

11 De La Sota RL, Lucy MC, Staples CR \& Thatcher WW. Effect of recombinant bovine somatotropin (sometribove) on ovarian function in lactating and nonlactating cows. Journal of Dairy Science $1993761002-1013$.

12 Gong JG, Campbell BK, Bramley TA \& Webb R. Treatment with recombinant bovine somatotrophin enhances ovarian follicle development and increases the secretion of insulin-like growth factor-I by ovarian follicles in ewes. Animal Reproduction Science $19964113-26$.

13 Sawyer HR, Wiepz GJ, Moeller CL, Nett TM \& Niswender GD. Failure of hypophysectomized ewes to ovulate in response to gonadotropins. Journal of Reproduction and Fertility 1991 Supplement 43 306-307.

14 Eckery DC, Moeller CL, Nett TM \& Sawyer HR. Recombinant bovine somatotropin (rbST, Sometribove) maintains the sensitivity of ovarian follicles to gonadotropins in hypophysectomized ewes. Biology of Reproduction 199348 Abstract 337 (Supplement 1).

15 Landefeld TD \& Suttie JM. Changes in messenger ribonucleic acid concentrations and plasma levels of growth hormone during the ovine estrous cycle and in response to exogenous estradiol. Endocrinology $19891251474-1478$.

16 Bíro J, Ritzén EM, Hall K \& Eneroth P. Effects of hysterectomy and uterine extracts on growth hormone, somatomedin, prolactin, thyrotrophin and thyroid hormones in adult rats. Acta Endocrinologica $1983103172-179$.

17 Bíro J, Ritzén EM, Hall K \& Eneroth P. Effects of hysterectomy and uterine extracts on the endocrine system of adult, nonpregnant rats. Journal of Steroid Biochemistry 198420 343-345.

18 Bíro J, Eneroth P \& Ritzén EM. Effects of hysterectomy and in vivo treatment with uterine extracts on plasma concentrations of growth hormone, thyrotrophin and thyroid hormone in rats: a kinetic study. Journal of Endocrinology $1984101243-$ 248.

19 Kann G. Evidence for a mammogenic role of growth hormone in ewes: effects of growth hormone-releasing factor during artificial induction of lactation. Journal of Animal Science $1997752541-$ 2549.

20 Merriam GR \& Wachter KW. Algorithms for the study of episodic hormone secretion. American Journal of Physiology 1982243 E310-E318.

21 SAS Guide for Personal Computers, version 6. Cary, NC, USA: Statistical Analysis System (SAS), 1987.

22 Blom AK, Hove K \& Nedkvitne JJ. Plasma insulin and growth hormone concentrations in pregnant sheep II: post-absorptive levels in mid- and late pregnancy. Acta Endocrinologica 197682 553-560.

23 Koritnik DR, Humphrey W, Kaltenbach CC \& Dunn TG. Effects of undernutrition on the development of the ovine fetus and the associated changes in growth hormone and prolactin. Biology of Reproduction 198124 125-137.

24 McMillen C, Thorburn GD \& Walker DW. Diurnal variations in plasma concentrations of cortisol, prolactin, growth hormone and glucose in the fetal sheep and pregnant ewe during late gestation. Journal of Endocrinology 1987114 65-72. 
25 Dutour A, Briard N, Guillaume V, Magnan E, Cataldi M, Sauze N \& Oliver C. Another view of $\mathrm{GH}$ neuroregulation: lessons from the sheep. European Journal of Endocrinology 1997136 553-565.

26 Klindt J, Robertson MC \& Friesen HG. Secretion of placental lactogen, growth hormone, and prolactin in late pregnant rats. Endocrinology 1981109 1492-1495.

27 Carlsson L, Edén S \& Jansson JO. The plasma pattern of growth hormone in conscious rats during late pregnancy. Journal of Endocrinology 1990124 191-198.

28 Chamley WA, Jonas HA \& Parr RA. Content of LH, FSH, and growth hormone in the pituitaries of pregnant and anestrous sheep. Endocrinology 197698 1535-1538.

29 Frankenne F, Closset J, Gomez F, Scippo ML, Smal J \& Hennen G. The physiology of growth hormone (GHs) in pregnant women and partial characterization of the placental GH variant. Journal of Clinical Endocrinology and Metabolism 198866 1171-1180.

30 Eriksson L, Frankenne F, Edén S, Hennen G \& von Schoultz B. Growth hormone 24-h serum profiles during pregnancy - lack of pulsatility for the secretion of the placental variant. British Journal of Obstetrics and Gynaecology 198996 949-953.

31 Frankenne F, Rentier-Delrue F, Scippo ML, Martial J \& Hennen G. Expression of the growth hormone variant gene in human placenta. Journal of Clinical Endocrinology and Metabolism 198764 635-637.

32 Eriksson L, Frankenne F, Edén S, Hennen G \& von Schoultz B. Growth hormone secretion during termination of pregnancy. Acta Obstetrica Gynecologica Scandinavica 198867 549-552.

33 Dlamini BJ, Li Y, Klindt J \& Anderson LL. Acute shifts in relaxin, progesterone, prolactin and growth hormone secretion in Chinese meisham gilts during late pregnancy and after hysterectomy. Journal of Animal Science 199573 3732-3742.
34 Kornalijnslijper JE, Kemp B, Bevers MM, Van Oord HA \& Taverne MA. Plasma prolactin, growth hormone and progesterone concentrations in pseudopregnant, hysterectomized and pregnant goats. Animal Reproduction Science 199749 169-178.

35 Al-Gubory KH \& Abdennebi L. Evidence that the conceptus contributes to the inhibition of follicular growth in the ewe. Animal Reproduction Science 199645 71-80.

36 Al-Gubory KH, Machelon V \& Nomé F. Evidence that a nonsteroidal factor from ovine placenta inhibits aromatase activity of granulosa cells in vitro. Comptes Rendus Hebdomadaire des Séances de l'Académie des Sciences 1995318 91-98.

37 Al-Gubory KH, Camous S, Soulier C, Martal J, Fevre J \& Driancourt MA. Evidence that placental factors contribute to the control of ovarian follicular activity in the ewe. Journal of Reproduction and Fertility 1997 Abstract Series No. 20, abstract 70.

38 Carlsson B, Nilsson A, Isaksson OGP \& Billig H. Growth hormonereceptor messenger RNA in the rat ovary: regulation and localisation. Molecular and Cellular Endocrinology 1993 95 59-66.

39 Eckery DC, Moeller CL, Nett TM \& Sawyer HR. Localization and quantification of binding sites for follicle-stimulating hormone, luteinizing hormone, growth hormone, and insulin-like growth factor I in sheep ovarian follicles. Biology of Reproduction 199757 507-513.

40 Chase CC. Kirby CJ. Hammond AC, Olson TA \& Lucy MC. Patterns of ovarian growth and development in cattle with a growth hormone receptor deficiency. Journal of Animal Science 199876 212-219.

Received 9 November 1998

Accepted 4 March 1999 